\title{
Places and "Non-Places": The Identity of a Place in the Perspective of Individual Memory and Social Forgetting
}

\begin{abstract}
The article deals with the issue of the identity of the place, taken in reference to the concept of places and non-places by Marc Augé. The main purpose of the theoretical analyses and analysis and interpretation of empirical results of the study was to determine the identity of the place (borderland) by referring to the individual memory of members of the minority group, inscribed in multifaceted, individual negotiations of experiencing the identity of the place. An important aspect discussed in the article are issues of social forgetting in Paul Connerton's approach and socio-cultural consequences of this process for the identity of the individual, group and place.

Narrative interview was the main form of data collection. The analyses are oriented to the variable of the identity of the borderland. The categories of the analysis refer to: the cultural identity of the borderland; personal memories of respondents related to the events, situations related to the past of their family; social memory of the minority group; social memory of the majority group. Memory of the borderland is a memory strongly embedded in a given area and unequivocally localized - assigned to a place "marked” and "embedded" culturally. This, of course, implies a series of difficult group-based negotiations regarding the contents of memory, places, events that, from the perspective of internal diversity of the group, may construct contradictory images of the past of the place.
\end{abstract}

\section{Keywords:}

place identity, individual memory, social forgetfulness

Faculty of Education, University of Białystok, Poland.

E-MAIL: jolamusz@uwb.edu.pl ORCID: 0000-0002-8116-4343 


\section{INTRODUCTION}

The category of "non-place” was taken from the work of Marc Augé (1995). The author treats "non-place" as a no-man's, non-historical, not possessing identity or possessing temporary identity space, produced by a hyper-modern man. "Nonplaces" are in opposition to places to which a person gives specific meanings, biographically inscribes them into own life and that of ancestors, and defines them through community life: “[...] place is formed by individual identities, through complicities of language, local references, the unformulated rules of living know-how [...]" (Augé, 1995, p. 101). It would seem, therefore, that the use of the "non-place" category in the case of the borderland is not justified because it does not fulfil the assumption of non-historicity, lack of identity - on the contrary, it is marked and embedded with identity, culture and history. The categories of memory and forgetting are equally important in the undertaken analyses. And while it is difficult to define who a "hyper-modern man" is, we are able to point the feature assigned to modern people - forgetting. Analysing the borderland, I notice ongoing processes of forgetting the identity of a place, the borderland identity, the consequences of which may lead to redefining borderland from the category of place to the category of "non-place", where spatial values are overcome by non-spatial values (political ideologies, global culture, consumerism), and the "non-place" there is a borderland in which the cultural past of a place becomes an object of tourist discoveries, an exotic corner of otherwise homogeneous Poland.

\section{THEORETICAL BACKGROUND}

Most contemporary researchers treat the borderland as a transcultural space. Manuel Castells noticed that the space is marked with "signs of power" and "with tangible realization of values" (Castells, 1982, p. 241). It is therefore a kind of a code, the content of which is filled by social structure and values, cultural symbols, characteristic to a given space. These observations of Castells confirm the thesis put forward many years earlier by Florian Znaniecki, in which he emphasized the importance of spatial values, which from the perspective of a specific group determine its status, durability and rules of participation (see: Wallis, 1990, p. 14). Both Znaniecki and Castells recognize that space takes on the meaning of a place in a situation where it is "marked" with values and culture. Space and place are symbiotically connected. The security that defines a place, according to Tuan, can only be made aware of when we notice the uncertainty of space. A place is 
a special type of object the greatest value of which is stability (Tuan, 1977, p. 12). Valuation of space, how its users mark it, clearly setting the boundary of "their" and "not their" places makes for the fact that the same place is not the same for co-participants of the operating environment.

From a cultural point of view, places are significant for specific individuals and communities. They are connected with a system of knowledge, imaginations and values, as well as rules of behaviour, thanks to which the process of identification and social integration takes place - therefore it is the culture of the place that "marks" them in the consciousness of an individual. The borderland is an ambivalent place, because in the perception of specific cultural groups it also consists of "non-places". If the place determines the identity of the group, interpersonal relationships are a non-place devoid of these properties (Augé, 1995). As a constitutive feature of the identity of individuals belonging to different cultural groups (in a marked and embedded place) individual memory vertically builds the collective memory of the community of the place.

\section{METHODOLOGY OF RESEARCH}

The main purpose of this study was to determine the identity of the place (borderland) by referring to the individual memory of members of the minority group, inscribed in multifaceted, individual negotiations of experiencing the identity of the place.

The methodology of qualitative research was adopted, and using a case study as a method related to the perception of social phenomena required from me an open approach (Hensel \& Glinka, 2012, pp. 90-91). Narrative interview was the main form of data collection. The main "direction" of my conversations (interviews) were issues related to the past of the place and the memory of it. My interviews do not have a strictly imposed, uniform structure. I recorded and later transcribed all interviews, staying close to the respondents' statements in their original wording.

I interviewed ${ }^{2}$ people varying in social roles, age and gender, related to the north eastern borderland of Poland through family history. I applied the snowball sampling method based on non-random sampling, recruitment of participants by other participants (Castillo, 2009). My analyses are oriented to the variable of the

Interviews were conducted in the years 2014-2016 among the residents of the villages of Narew, Trzcianka, and Bielsk Podlaski; in total, 15 interviews were conducted. 
identity of the borderland. The categories of the analysis refer to: the cultural identity of the borderland; personal memories of respondents related to the events, situations related to the past of their family; social memory of the minority group; social memory of the majority group.

\section{ANALYSIS AND INTERPRETATION OF THE RESEARCH RESULTS}

\section{IDENTITY OF THE BORDERLAND: THE PERSPECTIVE OF INDIVIDUAL MEMORY OF MEMBERS OF A MINORITY GROUP}

A place is always a distinct fragment of space, separated from the whole based on some special features as perceived by a subject. In the case of the borderland, these features are: ethnic and national intermingling, cultural heterogeneity as well as homogeneity. Ethnic and national intermingling build its multicultural landscape, create "borderline situations" in the psychological and cultural sense. A place is a space of everyday experiences of individuals and groups related to the realization of individual and social needs - the place of existential being and place as the space of being. As J. Kaczmarek (2005) emphasizes, for understanding and explaining the significance of a place, it is important to take into account the "ontological continuum of the place", in which the function of the place from the perspective of an individual becomes a vector between experiencing the place and its meaning. The "topology of being” (Kaczmarek, 2005) assumes an individual and social interpretation of the place, resulting from the significance of the place for a specific individual or group. What determines the perception of the meaning of a place is to a large extent related to the cumulative emotional sensations resulting from own and other experiences, present or past, marked with a specific cultural content.

Community memory is a smooth and dynamic reflection of the collective identity of the group and, as a result, is a strong predictor of group consolidation. Narratives based on community, shared experiences and memories build identity, hence memory and identity are mutually constitutive. Identities are narrative constructions that express individual perception of self in relation to others and depend on the reaction of the dominant socio-cultural group to its manifestations (Ryan, 2011, p. 156). D. Losch said that "the way we understand ourselves is at least partly the result of how others think about us" (Losch, 2003, p. 35). The community of the place and the memory of it are symbiotically dependent on one another. The communal memory of the place accentuates the difference, thereby emphasizing its own external image - it "marks" a place as its own. However, it 
often blurs it inside - and the remembered events are invoked due to responsibility, similarity and continuity (Assmann, 2008, p. 71).

"Here, the society was mixed, Belarusian-Polish. I say Belarusian-Polish as there were more Belarusians. In the municipality there is one Catholic church and there are a few Orthodox churches: in Trześcianka, in Narew, and in Łosinka. [...] There are more of us here, although in Poland we are a minority [...]". ${ }^{3}$ In the memories of the inhabitants of many borderland towns, the thread of the internal diversity of the group in which they lived is a constant motif of the narrative. "Before the war, in Bielsk lived primarily Belarusians, Orthodox. There were fewer Catholics. Several Gypsy families also lived on my street. I remember my first childhood love. It was a gypsy girl Murka, who was later burned during the war. The Germans gathered all the Gypsies and said they would take them to Bessarabia. Their horses and carts were taken away from them - and the Gypsies had good horses - and all this was taken away for the German army. The Gypsies themselves were transported to Treblinka by the Germans. My Mureczka too. My other love was a Jewish Girl Ester [...]. After the war, there were almost no Jews in Bielsko, only a few who were hidden by their neighbours, survived [...]". ${ }^{4}$

The subjective sense of multiculturalism arises from a series of differentia specifica of the place. The importance of multiculturalism for the identity of a place is related not so much to the fact that there are many cultures in place, but to the mental and emotional consequences of experiencing it by the individual. Time is one of the most important reference systems for shaping the sense of identity - of an individual and of a place. Thinking about the past, we place it in a specific social construct, we refer to specific rules of social life contained in the memories of what was, how it was - and what does not exist anymore. The memory of the past is the domain of the narrative of descending generations but also a kind of myth that establishes the truth about the present.

\section{SOCIAL FORGETTING AS AN ORDER OF COLLECTIVE MEMORY OF THE DOMINANT GROUP}

Forgetting is a conscious process and therefore has specific goals. Connerton distinguishes seven types of forgetting, assigning each of them a different social meaning (Connerton, 2008). The author perceives repressive erasure to be the most brutal form related to the goals of totalitarian rule; prescriptive forgetting is an order to remove from the social memory those elements of the past that in a way

\footnotetext{
Fragment of an interview with a 78-year-old teacher, a resident of Trzcianka.

4 Fragment of an interview with the 89-year-old resident of Bielsk Podlaski, a great-grandson of the president of Bielsk Podlaski during the time of the Russian partition
} 
change the present social relations; forgetting which is constitutive in the formation of a new identity; structural amnesia as remembering only those fragments from the past of the life of a community that are important nowadays; forgetting as annulment; forgetting as planned obsolescence; and forgetting as a humiliated silence. All seven types of forgetting do not create arbitrarily separate types of forgetting and what is more important, exist in the contemporary borderland to a greater or lesser extent, consequently changing its identity.

Referring to the genealogy studies of J. Barnes, P. Connerton assumes that as in the case of people, there is a tendency to remember in their pedigrees selective lines of ancestors - ones that were socially important, so does such a relationship occur in case of a society. Therefore, in collective memory events are selectively treated - ones important from the social perspective are remembered and commemorated, and others are forgotten. Selected fragments, social life events are recorded, marked by monuments - they are permanently inscribed in the past of people and places (formalized past - history), while the others are forgotten. M. Golka, referring to D. Schacter, talks about the "seven sins" of individual memory or (what I believe to be more adequate) individual non-memory. He distinguishes the sins of passing: impermanence, distraction, blocking, and sins of processing: erroneous attribution, susceptibility to suggestion, bias and persistence (Golka, 2010, pp. 51-53). The author suggests that it is difficult to see a direct analogy between individual and social non-memory. I believe that in the case of sins of processing, this analogy is clearly visible. Interpretation of erroneous attribution as an improper location of some of the memorized events in the time and space and the inappropriate source of knowledge that accompanies them are also present in social forgetting (structural amnesia). Just as susceptibility to suggestion based on filling the memory gaps with foreign (often media) content. Bias and persistence - adapting and engaging emotions - leads to a special type of arrangements regarding the past as well as the present. Structural amnesia is a manifestation of selective forgetting - the passages left behind or thrown out of social memory are those fragments which are uncomfortable from the perspective of the community. The main question in this context is the question about the said community. What kind of community are we talking about, what determines its shape? From the perspective of the borderland - the place "marked" by the identity and memory of individuals belonging to different cultural groups and having a different community memory - the decisive criterion becomes the categories "Us" and "Them". Only we cannot determine "Us" without "Them". The categories "Us" and "Them" take particular meaning in the borderland. For, on the one hand, "Us" are the inhabitants of a culturally diverse place, and "Them" are not 
some of these inhabitants - the external image of the group. On the other hand, "Us" means cultural homogeneity within the place, and "Them" are heterogeneous others in the space of a place. This specific identity dilemma of the community of borderland residents is strongly associated with tendentious forgetfulness and structural amnesia.

Most-minority relations are usually marked by the cultural dominance of the majority group. Similarly, in the case of remembering and forgetting. Collective memory is more one-sided, the events of the dominant group are emphasized and of the subordinated group - concealed or discreetly eliminated from memory. Because collective memory remains in relation with the present, structural amnesia, just like memory, has here a clearly defined function - legitimizing the dominant role of the majority group. Structural amnesia that occurs in the borderland manifests itself in various forms, e.g., in conscious actions related to the liquidation of monuments, changing street names or mythologisation of selected figures. In Bielsk Podlaski, which has already appeared in the above narrative as an internally culturally diverse place, we will not find, for example, street names validating the presence and memory of the Belarusian minority (just like in other borderland towns). We will find streets that refer to the memory of the dominant group. „[...] When it was necessary to name two new roundabouts in Bielsk, proposals were made to use the names of Father Jerzy Popiełuszko and 'Solidarity', and at that moment - if we have such a diverse environment - it was a bit wrong, but we have reached a compromise and one of the roundabouts is named after the 'Polish-Lithuanian Commonwealth'. One that in fact both reflects the historical context of these areas and highlights their present times, as the second was named after Father Jerzy Popiełuszko [...]". ${ }^{5}$ Is what the quoted respondent calls a compromise really that? Or maybe it is rather a case of appropriating space and remembrance about it, in the name of historical and political correctness? This manifestation of structural amnesia, unfortunately, does not apply only to Bielsk Podlaski or the Belarusian minority. Similar situations apply to the Lithuanian minority. ${ }^{6}$

5 Fragment of an interview with the member of the City Council of Bielsk Podlaski, representing the Belarusian minority in the council.

6 An example here is Sejny and the village of Bereźniki located in the Sejny municipality. In the case of the city of Sejny, there was a dispute over the location of the monument of Bishop Antanas Baranauskas. In the village of Bereźniki erected was a commemorative tombstone with a Lithuanian inscription: “Śp. Żołnierze Litewscy, którzy polegli za Wolność Ojczyzny w 1920 roku” ["RIP Lithuanian soldiers who died for Freedom of the Fatherland in 1920"]. This caused a very negative reaction of part of the Polish community, for which the tombstone became a symbol of the violation of the symmetry of shed blood (Wójcikowska, 2014). 
The identity of the place and the memory of the place connected with it depend, as M. Lewicka emphasizes (Lewicka, 2012, p. 439), on a number of cultural and political factors. The ideological message present in the media, publications (not only historical), displaying specific memorial sites, anniversary celebrations and the choice and manner of commemoration - all this creates a contemporary image of the place. Observing the contemporary way of political and social narrative present in our country, I get the impression that forgetting becomes an imperative to create a new (?) identity. The order of forgetting, just like other forms of memory, has a specific purpose - to erase those fragments of memory that do not serve contemporary social (and also political) interests. Throwing away from the memory of the nation the events and situations that do not match its contemporary vision, or ignoring and marginalizing the memory of other (culturally different groups) leads to antagonisms and radicalization of mutual attitudes. The display of national identity and the awakening of national consciousness usually appears in a situation of danger, when we try to define our belonging to a specific community. The subjective meaning of multiculturalism is associated with the awareness that "they" are different than just "my" identity, that there exist others - not only "my" group. This consciousness gives a person a direction and shapes their attitudes towards diversity. The aftermath of ideological and political shaping of attitudes towards diversity and multitude of cultures, consisting, among other things, of the order to forget or order to remember only convenient fragments are xenophobic and nationalistic attitudes. Political acceptance of the manifestation of nationalist beliefs and attitudes is a clear example of this.

"After the war it was hard as well... You Poles are saying AK [the Home Army] are heroes, Bury is a martyr, a hero... And here AK was murdering people... my friend's father organized GS after the war, after all, GS was a sort of municipal cooperative, but he was an activist, so they moved him out and today my friend does not know where her father's bones lay [...]". The character of "Bury", one of the "Cursed Soldiers" recalled by the respondent, is a model and symbol of patriotism for the All-Polish Youth and the Radical and National Camp. Both organizations are political groupings of fascist and nationalist character. It is these groups that have been organizing for several years Marsz Żołnierzy Wyklętych [A March of "Cursed Soldiers"] in Hajnówka - a place where the Belarusian minority and Orthodox believers make up the largest group - where the character of "Bury" becomes the hero of these lands. Not only in the memories of my interlocutor is "Bury" a controversial figure.

Fragment of an interview with a 78-year-old teacher, a resident of Trzcianka. 
The order of forgetting, the main purpose of which is to create a new identity (in the situation of the borderland - a new identity of the place), in Connerton's view assumes that in relation to higher than individual goals (e.g., in the situation of international conflicts) past actions should be not only forgiven, but also forgotten, and in this approach the order of forgetting is treated by the author as a category of profit. However, he further states that the practice of order of forgetting raises doubts and, consequently, is closer to loss than profit. In the situation of constructing a new identity, forgetting becomes a part of the process which is accompanied by the creation of new memories and the silent co-presence of the old, therefore the order to forget becomes an order of silence.

The memory of the place is also a memory of wrongs that are permanently woven into the fabric of everyday social life. Symbolic understanding - "knowhow" of a place, especially one marked with multiculturalism - requires an order of remembering and not forgetting. Using one concept of the national past in the social discourse, and the personal memories of the inhabitants overlapping with it, can create uncertainty about the future and the continuity and permanence of the place. It can also complicate or disrupt the community of the place (Baker, 2012, p. 27)

Like forgiving, forgetting constructs the identity of an individual. In the context of Giddens' assumptions, forgetting can be considered a "reflective interpretation”, especially when it concerns hard and traumatic memories. Studies on biographical memory conducted in Poland by Anna Rybak-Korneluk and her colleagues from the Medical University of Gdańsk have shown that "[...] memories were localized on the timeline in an asymmetrical manner. The happy and important events were placed early in life; the memories of sad experiences were located in a distributed way. It was most intensely expressed in the oldest age group [...]” (Rybak-Korneluk et al., 2016, pp. 962-963). And the oldest age group is one of the most important links in the biographical memory of the family and in group memory. The memory is sustained by a generation, which in Mannheim's understanding, does not mean a group of people of similar age, but a group having a shared place in the social and historical process, thus a group characterized by a sense of belonging and similar values. A special role of the older generation is the transmission of accumulated experiences, a specific cultural heritage that includes not only cultural content but, above all, their social interpretation and usability, which support the group's durability and better prepare the young generation to carry out the developmental tasks of the present and future (Mannheim, 1952, pp. 286-292). „[...] I personally owe all this to my grandmother. She lived for a very long time, to the age of 94 years, but I do not remember my grandmother 
from my father's family as he became an orphan when he was 7, after his family returned from bieżeństwo [translator's note: proper name of refuge of mostly Orthodox inhabitants of then Russian territories in 1915] after the First World War. Everyone was running away from the Germans, I do not know why, was it an order, or were they just afraid, I do not know how it was, in any case, almost everyone fled here. And later, to build a new life, I suspect that my grandmother from dad's family, Olga, died of hunger, because she had 7 children when they returned and had to feed everyone. They went begging, there on the Polish side near Brańsk, begging to feed the children, this beginning of the 1920s was terrible, and they lived in the dugouts [...]". ${ }^{8}$ The subject of bieżeństwo mentioned by the respondent is a traumatic event that has appeared in official social narratives only recently and in a very small extent. ${ }^{9}$ Such situations remain in collective memory, events that the group does not want to remember. So they are omitted with silence or repression. However, paradoxically, it is not an example of forgetting or nonmemory but of memory: of humiliation, pain, shame. Silence humiliated in the memory of a community has a therapeutic function and becomes a specific order of the group towards its members. While the order of silence may be effective in terms of group silence, it is more difficult to preserve it in individual autobiographical narratives of its members. What the group wants to forget or stay silent about, from a perspective of an individual may be an important trope building their identity.

\section{CONCLUSIONS}

The analyses of interviews presented in the article allow to formulate two conclusions. First, from the perspective of the minority group, the dominant narrative of the past is the history of the majority group, which consequently leads to overlooking the subjective experiences of the past of the members of the minority group. Secondly, such a social narrative changes the principle of equality and supremacy of the subjectivity of the individual and the subjectivity of minority groups in the

8 Fragment of an interview with a 78-year-old teacher, a resident of Trzcianka.

9 Anna Prymaka-Oniszk is the initiator of the wider context of social discourse on the theme of the flighting (journalist, author of the book "Bieżeństwo 1915. Zapomniani uchodźcy”, the initiator of the creation of the biezenstwo.pl website, and the competition "Jestem, bo wrócili" ["I am because they came back"], the outcomes of which in the form of reconstructed family memories of many people was published as a book with the same title. 
aspect of shaping cultural identity, and the perspective of status and social evaluation of culture limits the recognition of cultural diversity.

Research on social memory in Poland has been conducted for years. Their context is varied and the analyses refer to important contemporary aspects of the description of social relations in culturally diverse communities, and indicate the pedagogical values of the relationship between individual subjectivity, place and memory (Nikitorowicz, 2018; Sobecki, 2016; Mendel \& Theiss, 2019). The memory of a place, family memory are personal experiences of individuals, joining together to create a picture of the past, which is a legitimacy of the existing order, and this constructs the group's identity and the identity of the place.

Individual memory is not subjected to collective memory. Mnemonic resistance or resistance to the narrative of collective memory is possible, as collective memory is unquestionably constructed on individual memory (Ryan, 2011). Based on the theory of critical media, Lorraine Ryan constructs three categories of mnemonic resistance, i.e., hegemonic: consumers of memory interpret the cultural vector in the manner intended by its producer; negotiations: consumers of memory accept the general direction of the vector, but consider it irrelevant to their specific situation, and then proceed to integrate it with their own opposing view; oppositional: consumers of memory identify the interpretative code used by the producer and reject it in favour of an alternative (Ryan, 2011, p. 160).

Memory of the borderland is a memory strongly embedded in a given area and unequivocally localized - assigned to a place "marked" and "embedded" culturally. This, of course, implies a series of difficult group-based negotiations regarding the contents of memory, places, events that, from the perspective of internal diversity of the group, may construct contradictory images of the past of the place. The memory of the borderland should be transcultural, that is, as in the assumptions of Matthew Graves and Elizabeth Rechniewski, it should reject the concept of collective memory as a national memory, which implies the conflict nature of memory inside and beyond state borders. Graves and Rechniewski emphasize the need to distinguish the terms "international" and "transcultural”. The international approach goes beyond national borders, the transcultural approach refuses to recognize national borders and allows to consider not only cultures that can cross national borders, but the numerous and diverse ones that exist within them. The authors emphasize that in many European scientific studies on collective memory, intercultural diversity has become an integral part of biographical narratives (Graves \& Rechniewski, 2010). Transcultural memory in the approach of Astrid Erll is the constant movement of carriers, media, content, forms and practices of memory and constant changes in time and space that ignore social, linguistic and 
political boundaries. To understand what it is, one needs to realize that transcultural is part of the everyday individual experience of each person (Erll, 2011). The borderland is a special place for experiencing transcultural memory.

Memory of the borderland, referring only to the memory of nations inhabiting them, focuses on the struggle between nations, cultures and religions. However, such a context of remembering does not contain in itself the real everyday life of borderland inhabitants, and such a context of remembering omits the memory of ordinary people whose memories create an extraordinary memory of the place. Memory of the borderland includes also an awareness of the sins of forgetting. Forgetting (gradually) modifies the current norms of social coexistence, changes the image of the place, changes the image of the group, and changes us - it closes us in a homogeneous world. Thus, it becomes the greatest threat to the identity of the place - the identity of the borderland.

\section{References}

Assmann, J. (2008). Pamięć kulturowa. Pismo, zapamiętywanie i polityczna tożsamość w cywilizacjach starożytnych. Warszawa: Wydawnictwo Uniwersytetu Warszawskiego.

Augé, M. (1995). Non-Places: Introduction to an Anthropology of Supermodernity. Transl. J. Howe. London, New York: Verso.

Baker, K. (2012). Identity, Memory and Place. The Word Hoard, 1(1), pp. 23-33. Retrieved from: http://ir.lib.uwo.ca/wordhoard/vol1/iss1/4.

Buñuel, L. (2013). My Last Sigh. New York: Vintage.

Castells, M. (1982). Kwestia miejska. Foreword B. Jałowiecki. Transl. B. Jałowiecki, J. Piątkowski. Warszawa: Państwowe Wydawnictwo Naukowe.

Castillo, J.J. (2009, April 24). Snowball Sampling. Explorable.com. Retrieved from: http:// explorable.com/snowball-sampling.

Connerton, P. (2008). Seven Types of Forgetting. Memory Studies, 1(1), pp. 59-71. DOI: $10.1177 / 1750698007083889$.

Connerton, P. (2012). Jak społeczeństwa pamiętajq̨. Warszawa: Wydawnictwo Uniwersytetu Warszawskiego.

Erll, A. (2011). Traveling Memory. Paralax, 17(4), pp. 4-18. DOI: 10.1080/13534645.2011.6 05570.

Giddens, A. (2001). Nowoczesność i tożsamość. „Ja” i społeczeństwo w epoce późnej nowoczesności. Warszawa: Państwowe Wydawnictwa Naukowe.

Giddens, A. (2008). Socjologia. Warszawa: PWN.

Gills, J.R. (Ed.) (1994). Commemorations: The Politics of National Identity. New York, Princeton: Princeton University Press.

Golka, M. (2010). Społeczna niepamięć. Pomiędzy zapominaniem a zamazywaniem. In: S. Kapralski (Ed.), Pamięć, przestrzeń, tożsamość (pp. 49-71). Warszawa: Scholar. 
Graves, M., \& Rechniewski, E. (2010). From Collective Memory to Transcultural Remembrance. Portal: Journal of Multidisciplinary International Studies, 7(1): Fields of Remembrance, pp. 1-15.

Halbwachs, M. (2008). Społeczne ramy pamięci. Warszawa: PWN.

Harvey, D. (1989). The Condition of Postmodernity: An Enquiry into the Origins of Cultural Change. Oxford: Blackwell.

Hensel, P., \& Glinka, P. (2012). Teoria ugruntowana. In: D. Jemielniak (Ed.), Badania jakościowe. Vol. 1: Podejścia i teorie (pp. 89-113). Warszawa: PWN.

Jałowiecki, B. (2011). Miejsca, przestrzeń, obszar. Przegląd Socjologiczny, 60(2-3), pp. 9-28.

Kaczmarek, J. (2005). Podejście geobiograficzne w geografii społecznej. Zarys teorii i podstawy metodyczne. Łódź: Wydawnictwo UŁ.

Kozielecki, J. (1997). Transgresja i kultura. Warszawa: Wydawnictwo Akademickie Żak.

Kwiatkowski, T. (2008). Pamięć zbiorowa społeczeństwa polskiego w okresie transformacji. Warszawa: Scholar.

Lewicka, M. (2012). Psychologia miejsca. Warszawa: Scholar.

Losch, D. (2003). Bad Memories, The Poetics of Memory and the Difference of Culture. In: J. Bennett, \& R. Kennedy (Eds.), World Memory: Personal Trajectories in Global Time (pp. 30-43). London: Palgrave Macmillan.

Mannheim, K. (1952). The Problem of Generations. In: K. Mannheim, Essays on the Sociology of Knowledge (pp. 276-322). London: Routledge.

Mendel, M., \& Theiss, W. (Eds.) (2019). Pamięć i miejsce. Perspektywa społeczno-edukacyjna. Gdańsk: Wydawnictwo Uniwersytetu Gdańskiego.

Nikitorowicz, J. (2018). Etnopedagogika w kontekście wielokulturowości i ustawicznie kształtującej się tożsamości. Kraków: Oficyna Wydawnicza Impuls.

Nora, P. (2001). Czas pamięci. Transl. W. Dłuski. Res Publica Nowa, 7, pp. 37-43.

Ryan, L. (2011). Memory, Power and Resistance: The Anatomy of a Tripartite Relationship. Memory Studies, 4(2), pp. 154-169. DOI: 10.1177/1750698010366502.

Rybak-Korneluk, A., Wichowicz, H.M., Żuk, K., \& Dziurkowski, M. (2016). Pamięć autobiograficzna i jej znaczenie w wybranych zaburzeniach psychicznych. Psychiatria Polska, 50(5), pp. 959-972. DOI: 10.12740/PP/38518.

Schacter, D.L., \& Madore, K.P. (2016). Remembering the Past and Imagining the Future: Identifying and Enhancing the Contribution of Episodic Memory. Memory Studies, 9(3), pp. 245-255. DOI: 10.1177/1750698016645230.

Sobecki, M. (2016). Komunikacja międzykulturowa w perspektywie pedagogicznej. Studium z pogranicza polsko-litewsko-białorusko-ukraińskiego. Warszawa: Wydawnictwo Akademickie Żak.

Tuan, Yi-Fu. (1977). Space and Place: The Perspective of Experience. Minneapolis-London: University of Minnesota Press

Wallis, A. (1967). Socjologia wielkiego miasta. Warszawa: PWN.

Wallis, A. (1990). Socjologia przestrzeni. Warszawa: Niezależna Oficyna Wydawnicza.

Wójcikowska, K. (2014). Walka o miejsca pamięci w przestrzeni dwunarodowej gminy Sejny. Pogranicze. Studia Społeczne, 23, pp. 65-82. 